DOI https://doi.org/10.30525/978-9934-588-86-0.14

NEW GUIDELINES IN PROJECT AND LOGISTIC MANAGEMENT

\author{
Lapkina I. O., Semenchuk K. L., Shutenko T. M.
}

"Business value in projects refers to the benefit that the results of a specific project provide to its stakeholders. The benefit from projects may be tangible, intangible, or both" .

"An important goal of SCM has always been building new capabilities of participating companies that will enable them to have an advantage over their competitors $"$.

\title{
INTRODUCTION
}

The current stage of project and program management development is characterized by the following trends ${ }^{3}$ :

- the reduction of the product life cycle of the project;

- digitalization of all processes, transition from offline to online mode;

- globalization of markets, innovative development of competitors and the inability of national companies to withstand such pressure;

- agile-transformation and projectization of business. So, according to the job search site Glassdoor ${ }^{4}$, the most desired profession is a project manager, then a business analyst, data researcher, and software developer.

Odessa National Maritime University has been tracking the trends of interest for project manager profession since 2001, and has been training Masters in an educational and professional program (EPP) "Project Management". The purpose of this EPP under 073 specialty "Management" is to train a new generation of highly skilled managers that meet the dynamic changing requirements of the modern job market and international level of

${ }^{1}$ Asthana, S. G. (2018). Making Sense of Supply Chain 4.0: what, exactly, can 'digital transformation' improve upon? Industryweek. URL: https://www.industryweek.com/supplychain/article/22026620/making-sense-of-supply-chain-40 (accessed 20 April 2020).

${ }^{2}$ Bushuyev S. D. (2018). Rukovodstvo IPMA ICB4 v mire Agile [Agile IPMA ICB4 Guide], 72 p. [in Russian].

3 Reyting luchshikh professiy po versii Glassdoor [Glassdoor Ranking Best Professions] (2017). URL: https://hightech.fm/2017/01/25/glassdoor-2.

${ }^{4}$ Lapkina I. A., Pavlovskaya L. A., Boldyreva T. V. \& Shutenko T. N. (2008). Proyektniy analiz. Teoreticheskiye osnovy otsenki proektov na morskom transporte. Odessa : ONMU, 367 p. [in Russian]. 
vocational education; managers who obtain modern methods of effective management, strategic thinking, systematic notion, knowledge, and skills in the field of project management (PM), with taking into account the specifics of maritime transport ${ }^{5,6,7,8}$. Currently, the University has a degree system of training in this specialty, which includes the training of specialists from bachelor to research staff in graduate and doctoral studies. The Department of "Logistics Systems and Projects Management" constantly monitors the requirements of the job market for new professions, which is reflected in the educational process and researches of the department.

PM is a field of activity that requires not only professional competencies (knowledge, skills, and practical abilities), but also certain personal qualities (motives, values, and beliefs). International Project Management Association (IPMA), given the experience of national associations of different countries, has developed a competency evaluation for project managers and executives certification". The competency model "Eye" includes technical, behavioral, and contextual components ${ }^{10}$. The IPMA Individual Competence Guide (ICB4) describes how different elements of competence can be interpreted in Agile environment. There are three areas of competence: perspective, people, and practice, each of which includes a number of elements of competence, a total of 29.

Turning to the Classifier of Professions of Ukraine ${ }^{11}$, one can see that it doesn't display all current positions. In the search of the word "Project",

${ }^{5}$ Lapkina I. O., Semenchuk K. L. (2014). Upravlinnya protsesamy v proyekti. Odesa: ONMU, 115 p. ISBN 978-966-7716-74-5. [in Ukrainian].

${ }^{6}$ Semenchuk K. L. (2012). Stratehichnyy menedzhment. Praktykum z obgruntuvannya stratehichnykh rishen' dlya transportnykh pidpryyemstv. Odesa: ONMU, 2012, 228 p. ISBN 978-966-7716-68-4. [in Ukrainian].

7 Lapkina I. (2015). Risk management in syllabuses of Odessa National Maritime University [Risk management and assessment for prevention of ecological and technological risk in the Black Sea basin. 09-12 July 2015, Burgas, Project 2.2.21.73194.264 "Creation of Interuniversity center for risk management and assessment for prevention of ecological and technological risk in the Black Sea basin. Joint Operational Programme "BLACK SEA BASIN" for Romania]. Conctanta: Editura Nautica, pp. 504505. ISBN 978-606-681-069-2.

${ }^{8}$ ICB. IPMA Competence Baseline (2006). [IPMA, Version 3.0], 199 p.

${ }^{9}$ Bushuyev S. D. (2010). Upravleniye proêktami: osnovy professional'nykh znaniy i sistema otsenki kompetentnosti proêktnogo menedzhmenta [National Competence Baseline, NCB UA Version 3.1] / Bushuyev S.D., Bushuyeva N.S. Second edition. K.: ÍRÍDÍUM. 208 p. [in Russian].

${ }_{10}$ Klasifikator profesiy Ukrayiny DK 003:2010. URL: https://buhgalter911.com/ spravochniki/ klassifikatory/klasifikator-profesiy.

11 V Davose obsuzhdali neobkhodimost' mirovoy revolyutsii po pereobucheniyu kadrov: prichina. URL: https: https://rubryka.com/ru/2020/01/26/retraining-personneldavos/. 
Classifier provides senior architect, senior designer, senior engineer, senior constructor, etc., but those are traditional positions, which derived from the definition of "project", where project implied only drawings, estimates and an appropriate set of documentation, which currently does not correspond to modern ideas. Under code 1238 there is "Project and programme leader in the field of material (immaterial) production". The classifier includes the position of "Manager" of logistics, marketing, consulting services organization, staff, regional development, delivery, advertising, with monetary intermediation, ICT, etc., but with no relationship to the project. Also, it should be noted that the Classifier does not reflect the range of professions based on modern knowledge and skills of project management, because the state of professional PM activity has a significant impact on the development of Agile environment, creating a list of new professions that need detailed consideration.

\section{PROJECT MANAGEMENT AGILE-SPECIALISTS}

In the upcoming years, "the skills needed to do most of the jobs will change significantly", warns the World Economic Forum ${ }^{12}$. According to experts, the development of artificial intelligence, technological breakthroughs, analytics of large data sets, "cloud" technologies, the "Internet of Things" will inevitably lead to the need for professionals who will have to learn throughout life.

Agile specialists or flexible leaders are able to achieve project results with available tools and resources, implemented by systemic and strategic thinking, as well as ingenuity and situational approach, which allows you to use any changes to ensure a project with competitive advantages in dynamic environment. At the moment, there is a need for competent Agile specialists who must have the ability to constantly develop, have the motivation to adapt and grow, which stimulates the project team to these changes. Accordingly, a list of competencies of Agile specialists with their detailed description is defined $^{13}$.

We will look at the list of professions that belong to the field of PM. Among them are the most important from the point of view of today's positions, such as project manager, project curator, project administrator, technical project manager, business development manager, investment specialist, HR manager, communications manager, contract manager, PR manager, event manager, fundraiser, manager of an Internet project,

12 Semenchuk K. L. (2020). Upravlinnya proektamy Agile-spetsialistamy [Project Management of Agile Specialist]. Development of Management and entrepreneurship methods on transport, no. 2(71). [in Ukrainian].

${ }^{13}$ Proyektnyy ta lohistychnyy menedzhment: novi znannya na bazi dvokh metodolohiy. (2018). Tom 1: monohrafiya / [avt. kol: S.V. Rudenko, I. O. Lapkina, T. A. Kovtun ta in.]. Odesa. 188 p. DOI: 10.21893/2616-8936.2018-01. [in Ukrainian]. 
performance manager, specialist in the promotion of goods and services. A special place in this list is occupied by specialists in the design and efficient operation of logistics systems and supply chains. These include the following.

Project Logistics Specialist - ensures timely delivery of various resources to the project with minimal costs, forms and optimizes stocks of resources, implements logistics of project deliveries.

Supply and Sales Specialist - plans and controls the transportation of resources, selection of suppliers of works, resources, and services in the project, organizes procurement and supply of resources, sending orders to suppliers, work with customs, insurance, and brokerage companies.

Specialist in the Design and Management of Supply Chains - manages the entire complex of logistics operations in the project, develops logistics schemes, reduces logistics costs, manages inventory.

All over the world, as well as in Ukraine, the number of specialists who are opening to new knowledge is increasing. Among the forecasted topical skills: systems and strategic thinking, IT-technologies (artificial intelligence), work in the conditions of Agile and uncertainty, intersectoral communication, project management. The Agile approach includes ideas on the basis of which some flexible methods have been developed, for example, Scrum framework, Lean, Kanban, 6 sigma, Just in time, etc. These methods came from logistics to project activities because, in conditions of fierce competition in the markets of suppliers and consumers of resources, the search for new forms of business management requires the use of a symbiosis of methods of logistics and project management.

The potential of logistics and PM is realized in providing:

- material and technical - purchase and delivery of materials, equipment, etc.;

- financial - search and attraction of investments;

- information - systematization and accumulation, processing of information;

- personnel - the selection of the project team, staff development;

- legal - legal support of the project throughout its lifecycle.

Supply-sharing methodologies include supply chain management and project management ${ }^{14,15}$. The development of theoretical foundations and practical skills of these fields of knowledge makes it possible to obtain a synergistic effect in resource provision. Today, dynamic (Agile) supply chains

${ }^{14}$ Pryektnyy ta lohistychnyy menedzhment: novi znannya na bazi dvokh metodolohiy. (2019). Tom 2: monohrafiya / [avt. kol.: I. O. Lapkina, V. O. Andryyevs'ka, V. Yu. Smrkovs'ka ta in.]. Odesa. 242 p. DOI: 10.21893/2616-8936.2019-02. [in Ukrainian].

15 Kubasova T. I. (2009). Logistika i logisticheskiy menedzhment ipotechnostroitel'nykh proyektov [Logistics and logistics management of mortgage construction projects]. Sankt-Peterburg: Sankt-Peterburgskogo gos. un-ta ekonomiki i finansov. 250 p. [in Russian]. 
have become increasingly popular, the essence of which is to increase the level of service by increasing the speed of response to consumer inquiries and flexibility in excess components (high inventory, the presence of distribution centers near consumers, etc.) given the uncertainty in the supply chain. Management of such supply chains requires a holistic business strategy aimed at increasing competitiveness of participating companies in accordance, on the one hand, - with customer values, and on the other, - with minimal costs.

\section{LOGISTICS IN PROJECT MANAGEMENT \\ The bases of supply chain design}

The issue of determining the composition of logistics functions and operations, inventory management strategies in the supply chain (SC) happens at the stage of developing a business plan for the project. During the project implementation, logistics covers almost the entire range of resource and functional support from the processes of initiation to closure. Logistics in the PM should be considered more broadly than resource management in the project, namely - as a certain strategic concept. The content of this concept is reflected in the concept of "project logistics management" - a systemorganized process of managing investment, material, service, financial, information flows of the project, which is implemented in a sequence of phases, stages and life cycle according to logistics rules through supply chains and interaction participants ${ }^{16}$.

The ability to create an effective SC is an important feature of the organization since the SC provides or limits the organization's competitiveness. As competition moves from competition between organizations to competition between supply chains, the SC design becomes a key source of competitive advantage and a decisive factor in determining the efficiency and effectiveness of the entire supply chain ${ }^{17,18}$.

For the first time, the phenomenon of the SC control was at a crossroads in the late 1990s, when companies realized that the regulations on the SC were written in the $1950 \mathrm{~s}^{19}$, should be adapted for an era of increasing global competition. The SC control phenomenon again reached a turning point in the

${ }^{16}$ Reeve J. M. \& Srinivasan M. M. (2005). Which supply chain design is right for you? [Supply Chain Management Review], pp 50-57.

17 Semenchuk Ye. L., Shutenko T. N. (2015). Integratsiya sudokhodnoy kompanii v tsepyakh postavok [Integration of the shipping company in supply chain]. East Ukraine National University of V. Dahl, no. 2 (219), pp. 18-22. [in Russian].

${ }^{18}$ Forrester J. W. (1958). Industrial Dynamics: A Major Breakthrough for Decision Makers. [Harvard Business Review]. no. 36 (4), pp. 37-66.

${ }^{19}$ Soonhong Min, Zach G. Zacharia, and Carlo D. Smith. (2019). Defining Supply Chain Management: In the Past, Present, and Future. Journal of Business Logistics. No. 40(1), pp. 44-55. 
era of Industry 4.0 (Fourth Industrial Revolution), which is associated with the rapid development of information technology ${ }^{20}$.

Organizations such as the Association for Supply Chain Management (ASCM), Project Management Institute (PMI), Council of Supply Chain Management Professionals (CSCMP), and Operations Management Association (APICS) have made significant contributions to the study, development of a modern concept, and the implementation of an effective SC. As a result of the joint efforts of scientists and practitioners, the supply chain capabilities of business structures have expanded from the integration of forecasting, planning, and execution of operations to uninterrupted management from the beginning to the end of the SC.

$S C$ design is a complex process by which an organization forms the structure and manages the SC in order to ensure the necessary balance between inventory, transportation, and production costs.

SC design can be done in three steps ${ }^{21}$ :

1. Understanding the nature of the needs of the end users of the SC and how these needs can be met.

2. Justification and choice of the SC strategy, taking into account the possibility of satisfying the needs of its end users.

3. Construction of the SC structure. This includes selecting SC partners, assigning roles and responsibilities to each participant, deciding how to use SC drivers, and determining key performance indicators (KPIs).

The idea of a balanced solution to production and distribution problems is based on a logistic approach. CSCMP defines "logistics" as the "base of the SC process that plans, implements and controls the efficient movement and storage of goods, services and related information from the point of origin to the point of consumption in order to meet customer needs". Logistic operations are important components for the functioning of the SC. Logistics, by synchronizing the supply, sales, storage, and delivery processes in the logistics systems, performs an integrating function in the SC. Logistic systems design ${ }^{22}$ is a component of the design of the SC structure.

The object of control in the logistics system is the material flow, which, for example, in the delivery system is presented as cargo. The control object in the $\mathrm{SC}$ is the material flow, considered in three states - material resources, work in

${ }^{20}$ Nel J. D., Badenhorst-Weiss. (2010). Supply chain design Some critical questions. URL: https://www.researchgate.net/publication/307846614_(accessed 25 April 2020).

21 Shutenko T. N. (2011). Analiz sredy funktsionirovaniya logisticheskoy sistemy. [Analiz sredy funktsionirovaniya logisticheskoy sistemy.]. Proceeding of the Odessa National Maritime University. Odessa : Astroprint, no. 32, pp. 195-203. (in Ukrainian).

22 Apics Supply Chain Council. (2015). Enhancing Project Management. URL: http://www.apics.org/docs/default-source/industry-content/apics-enhancing-project. (accessed 20.04.20). 
progress, finished products. Strategic business decisions in the supply chain are often associated with the implementation of various logistics projects, and effective operational management and development projects are integral components of management in the SC.

As is known, PM is a methodology for creating structures and predictability from complexity. PM provides unique project requirements for the formation of dynamic relationships between supply chain participants inside and outside organizations ${ }^{23}$.

The methodological foundations of logistics, PM, and SC are the basis of the concept of supply chain project management.

Project management in the supply chain is a process that allows you to coordinate resources and actions to achieve a specific goal on time, budget, and boundaries (APICS). PM in the supply chain creates order and predictability among complex and variable requirements. The tactics, resources, and changes that must occur become concrete and measurable in advance. The same tactics organize communication and behavior in predictable terms. PM in the supply chain expands the capabilities of supply chain professionals, including forecasting, customer service skills, planning, and risk management.

A successful PM in the supply chain turns ideas into practical endeavors.

\section{Supply chain project outcomes}

The Project Management Institute's Guide to the Project Management Body of Knowledge (PMBoK) defines project objectives, outcomes, and outputs as follows:

- Project objectives are quantifiable criteria that must be met for a project to be considered successful. Each quantifiable criterion includes an attribute (e.g. cost), metric (unit of measure), and is expressed either as a single value or range of values.

- Project outcomes are either tangible or intangible. The examples cited by the PMBOK are tangible outcomes such as buildings and roads and intangible outcomes such as people who can effectively apply their training.

- Project deliverables (outputs) are "any measurable, tangible, verifiable outcomes, results or items that must be produced to complete a project or a part of a project".

The project outcome can take the shape of a product, a service, or a result $^{24}$. In the multiple organization of the supply chain, products take many

23 James B. Ayers. (2006). Handbook of supply chain management. [Auerbach Publication, $2^{\text {nd }}$ ed]. $658 \mathrm{p}$.

24 Semenchuk Ye.L. (2011). Stratehyy razvytyya sohlasno zhyznennomu tsyklu sudokhodnoy kompanyy. [The strategic development is according with the life cycle of the shipping company]. Proceeding of the Odessa National Maritime University, Odessa : ONMU. No. 32. pp. 161-169. [in Russian]. 
forms. The right choice of product, service, or result is important for the supply chain project.

Table 1

Supply chain project outcomes

\begin{tabular}{|c|l|l|}
\hline $\begin{array}{c}\text { Project } \\
\text { outcome } \\
\text { type }\end{array}$ & \multicolumn{1}{|c|}{ Nature of the Outcome } & \multicolumn{1}{c|}{ Examples } \\
\hline Result & $\begin{array}{l}\text { Broadest and the longest in terms of } \\
\text { ability to evaluate achievement } \\
\text { Useful in defining services and } \\
\text { products for future deliverables, } \\
\text { downstream projects, or subprojects } \\
\text { Most amount of latitude in terms of } \\
\text { the final product }\end{array}$ & $\begin{array}{l}\text { "Perfect Order" as defined by } \\
\text { selected metrics } \\
\text { Bill of material cost reduction goal } \\
\text { A goal for gaining new customers in } \\
\text { an underserved segment }\end{array}$ \\
\hline Services & $\begin{array}{l}\text { Intermediate term } \\
\text { Probably many paths to produce the } \\
\text { deliverable } \\
\text { Amenable to the use of Activity } \\
\text { Systems in the design }\end{array}$ & $\begin{array}{l}\text { A new business model for customer } \\
\text { service } \\
\text { Developing an "enabling" supply } \\
\text { chain process } \\
\text { A new supply chain for a new } \\
\text { product }\end{array}$ \\
\hline \multirow{2}{*}{ Product } & $\begin{array}{l}\text { Shortest term } \\
\text { Easiest to define when it is complete } \\
\text { Often support a service or a result } \\
\text { Least amount of latitude in terms of } \\
\text { the final product }\end{array}$ & $\begin{array}{l}\text { A supply chain strategy based on the } \\
\text { company's strategic plan } \\
\text { A collaboration strategy for trading } \\
\text { partnerships } \\
\text { A new warehouse } \\
\text { An implemented supply chain } \\
\text { information system }\end{array}$ \\
\hline
\end{tabular}

\section{Supply chain project life-cycle phases}

Successful project implementation in the supply chain is not an easy endeavor. It calls solving a series of tasks to meet stakeholder and client requirements; a lot is involved in the process before the project reaches the completion phase. In this process knowledge about the project management life cycle is essential. No less important point in the supply chain development or improvement projects is the strategy implementation process (Fig. 1).

Phase 1 develops the strategy, including documentation and evaluation, the definition of the destination, and identification of gaps and root causes. Phase 2 implements the strategy, addresses the barriers to improvement. These barriers are lack of focus, confusion about technology and costs, motivators, boundaries, and slowness due to rigidity. 


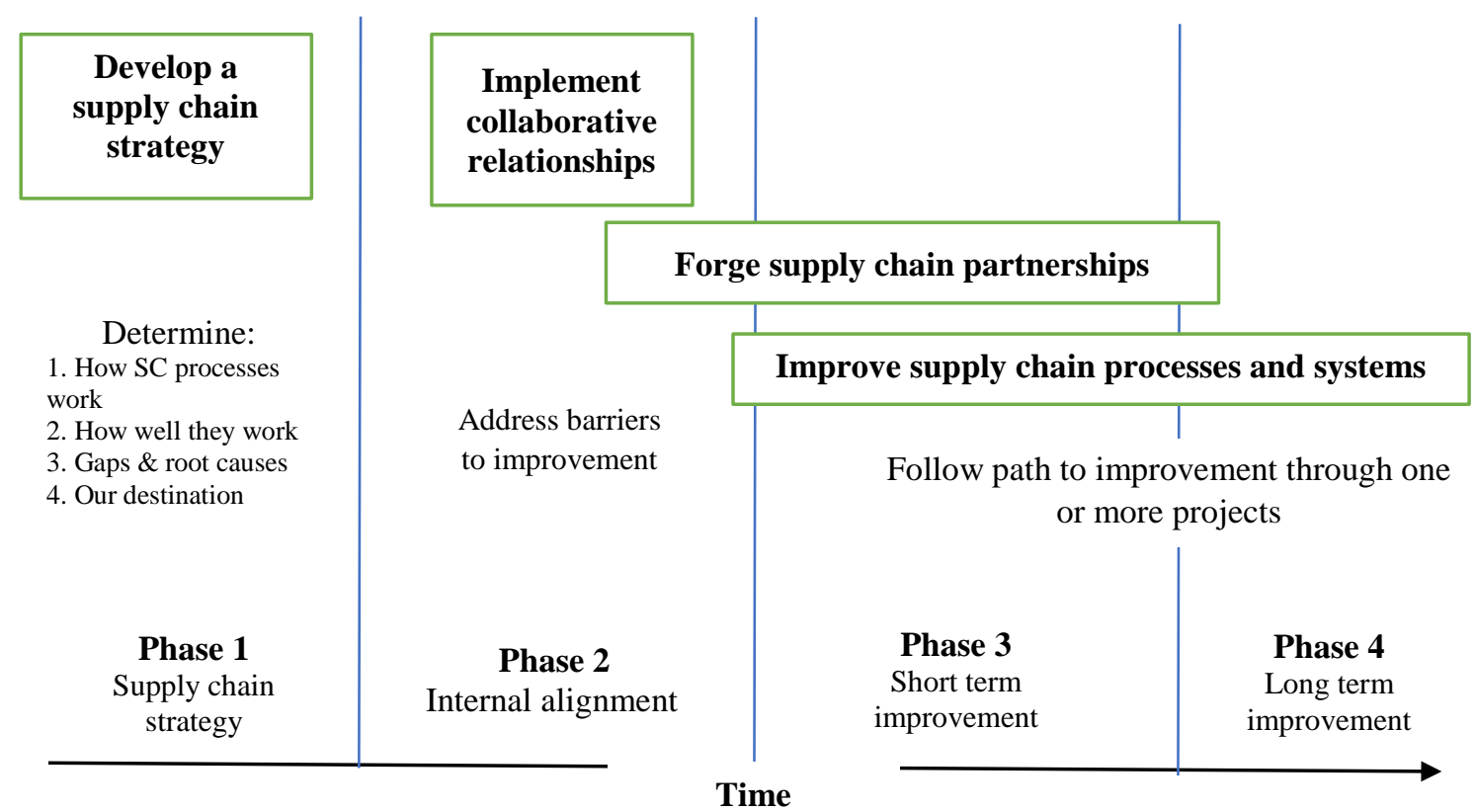

Fig. 1. SCM project mie-cycle phases

Phase 3 and 4 are process and systems improvement or sub-projects that are short and long term. A short - or long-term frame will depend on the company and the pace of change possible. A "short" Phase 3 project is likely to require one to two years to complete; the "long" is beyond that horizon. Long-term project examples include new facilities and systems ${ }^{25}$.

A good example of a long-term project in the SC is the ship acquisition project. It can be represented as a sequence of six phases. The first phase is the preparation of proposals for the formation of requirements for the object and the initiation of the project.

Design is an indispensable element in the process of updating equipment and the fleet, in particular. At this stage, the life-cycle (LC) needs to be carefully studied. The conditions for the acquisition of ships in the domestic and world markets should be compared and evaluated, first of all, in connection with the increasing requirements regarding the safety of navigation, the protection of human life and the environment, and also consider the conjuncture of the freight market. Ship design is carried out by specialized design organizations that have the appropriate licenses. Financing of such

25 Semenchuk Ye. L. (2007). Videniye zhiznennogo tsikla proyekta razvitiya sudokhodnoy kompanii s pozitsiy razlichnykh yego uchastnikov. [Vision of the life cycle of a shipping company development project from the perspective of its various participants]. Project Management and development of production. Lugansk: V. Dahlya of SNU, no. 3 (23), pp. 95-102. [in Russian]. 
works is carried out, as a rule, at the expense of the shipping company (customer).

When preparing a proposal for a construction contract, the contractor specifies strategic decisions with the customer. The project participants are determined, the timing of the project is specified, the schedule is compiled.

The implemented project goes through all phases of the LC, each of which has a wide circle of participants, and the overall level of project efficiency is formed under the influence of the management methods used.

In fig. 2 there is a specified vessel's life cycle from the perspective of different participants in the fleet renewal (replenishment) project ${ }^{26}$. Dashed arrows indicate the continuity of the project implementation process since the development of the plan begins at the pre-investment stage. It should be noted that for the investor, the LC of the project can be completed at various points in time, depending on the conditions for paying its arrears of credit debt; a similar situation is reflected by several arrows. Such situations can be caused by various loan repayment schemes (straight-line, uneven schemes, with the provision of a grace period, as well as with the possible early repayment of credit debt).

\section{Supply chain strategy development}

The strategic nature of cooperation between SC participants is aimed at providing quality customer service. Each participant in the SC, regardless of its size and production profile, can fulfill its function due to the fact that there are customers who are ready to buy its goods or services. Consequently, the SC should be structured in such a way as to connect the links that have a direct or indirect impact on the final consumer, creating value for the buyer both in relation to the product and the entire logistics service. The logistics system created by all parts of the SC should be designed in such a way as to take into account the results of the market analysis conducted taking into account the needs of various customer groups.

SCs must have their own strategies. If the goal of all efforts is the final recipient, then the strategic decisions of the SC include:

1. The study of demand for a product, product features.

2. Contractual relations between participants in the SC.

3. Selection of suppliers, distribution channels, location of warehouse space, transportation services, etc.

4. Inventory management concept.

5. Identification of key competencies of the $\mathrm{SC}$ as a whole and its main elements.

6. Supply chain design and flow chain planning.

7. Configuring the SC, deciding to "make or buy."

26 Lee H.L. (2005). Sekret najbardziej efektywnych łańcuchów dostaw. [Harvard Business Review Polska]. no. 25, pp. 78-92. 


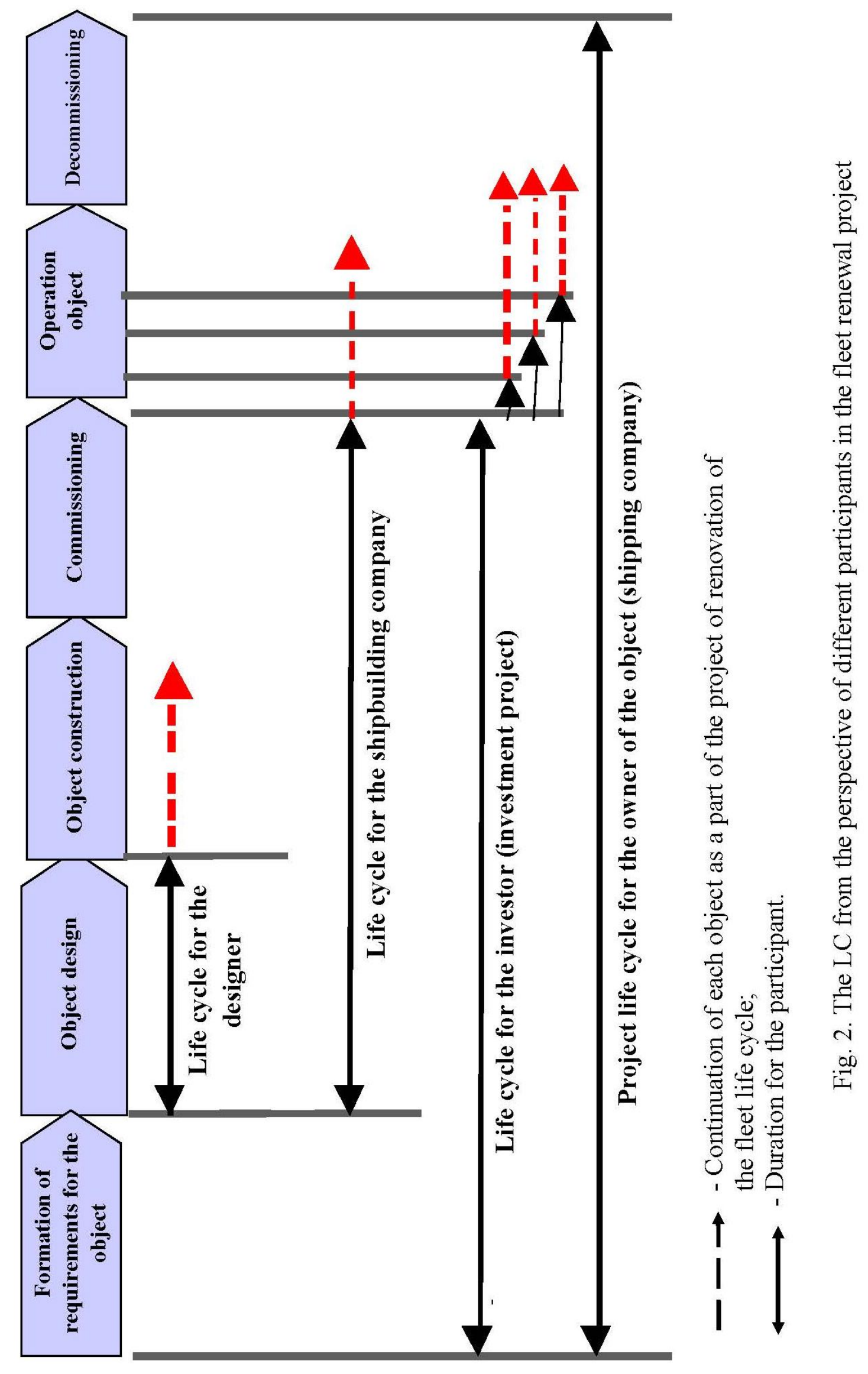


The focus of the SC on the client is most clearly emphasized by the Quick Response concept $(\mathrm{QR})$. It consists in determining the demand and quick response to its changes, in closer cooperation between the participants of the $\mathrm{SC}$ in order to provide a high level of customer service at minimal cost. This is possible if customers quickly provide their suppliers with the necessary information on demand, and suppliers are required to provide quick deliveries, offering a high level of service, properly managing inventory, using modern logistics technologies, in particular Electronic Data Interchange (EDI). This, obviously, requires partnerships in the SC, a shorter time frame, the exchange of information (in particular, information about stocks), quality obligations (Total Quality Management, TQM), fast transportation and reorganization of production operations, as well as reducing the time required to switch production. Thanks to better customer service, these operations lead to increased supplies and lower costs, bringing benefits to all SC participants.

The flexibility of supply or, more broadly, the flexibility of suppliers is becoming increasingly relevant. This is applied to strategic supply chain activities. Thus, the problem lies in the flexibility of individual participants in the SC, namely, suppliers and consumers. The flexibility of the entire SC is the ability to adapt to changes in market structures and changes in strategy ${ }^{27}$.

Strategies based on the concepts of Lean Management and Agile Management can be helpful in meeting agility requirements. These concepts can be applied both to the company and to the entire SC. Lean Management is aimed primarily at reducing costs. Such management creates value for the client, eliminating all losses, such as stocks of work in progress, production losses, assuming fast delivery and no shortage of stocks.

On the other hand, Agile Management is primarily aimed at quickly responding to changes in demand both quantitatively and qualitatively. In this case, the strategy of the companies is the perfect end user service. Key features of this strategy include flexibility and short delivery times. Agile SC strategies are best for differentiated products in the face of changing demand. This strategy is the easiest to implement when the total lead time is shorter.

However, in reality, these two approaches can complement each other, and in many cases a hybrid strategy is used that uses both lean and agile SCs "Leagile"28.

Considering the main goals of SC management, we can distinguish the following:

${ }^{27}$ Mason-Jones, R., Naylor, B. \& Towill, D. R. (2000). Lean, agile or leagile? Matching your supply chain to the marketplace. [International Journal of Production Research], no. 38(17). pp. 4061-4070.

${ }^{28}$ K. Behrenbeck, A. Brinkhoff, J. Grobpietsch. (2008). How to become a Supply Chain Champion. Hard fact about soft factors. [McKinsey\&Company], 173 p. 
1. Reducing the overall Lead Time;

2. Ensuring reliability, the correct frequency of delivery (Tack Time), quality and flexibility of supply (Agile Management);

3. Optimization of inventory levels throughout the supply chain;

4. Minimization of total costs.

Inventory optimization means that inventory management cannot be seen as an autonomous activity, inventory levels must be flexibly adjusted to customer preferences. Minimized total costs for the flow of material resources should be compared with the level of delivery service, as this is the main compromise of the entire logistics system.

It should be noted that individual companies in the SC are suppliers and consumers at the same time. Each supplier is a customer of another supplier, which means that they all must operate in two markets: they are part of the sales market as customers, and as suppliers in the procurement sphere. Each company in the SC should listen to the signals of the customer market - in this case, study the needs of the next link and, having received the necessary knowledge, purchase the necessary resources in the market, i.e. from the previous link in the SC.

\section{MODELLING OF SUPPLY CHAIN VALUE CREATION}

\section{Indicators of supply chain service quality (Service Level \& Fill Rate)}

The main indicators related to the processes of design and organization of effective operation of the SC are:

- Lead Time $(L T)$ - the period from the moment of placing a request for a resource to the supplier to the moment of the possibility of outloading to the consumer.

- Planning Time-frame - the term for which a plan or program of action is supposed to be implemented. For SC - the period during which the demand will be provided with a given level of service after receipt of goods in the warehouse.

- Order Frequency $(O F)$ - the period between the two coming orders.

- A deficit in inventory management - an event that shows the excess demand for a resource over available stock.

- Weighted Average Cost of Capital (WACC) - the average interest rate on all sources of financing the company.

- Service Level (SL) - an indicator of the quality of SC counterparties.

The components of the cost of the SC are the service level, logistics costs, daily storage costs (Fig. 3$)^{29}$.

${ }^{29}$ Garrison A., Van Gok R. (2010). Logistika. Strategiya upravleniya i konkurirovaniya cherez tsepochki postavok. [Logistics. Supply Chain Management and Competition Strategy]. Moskow: Delo i Servis. 368 p. [in Russian]. 
To determine the optimal strategy for the design and operation of the SC, it is necessary to take into account the economic compromise between the cost of resource shortages and the cost of maintaining excess stocks. The key task is to determine the service level.

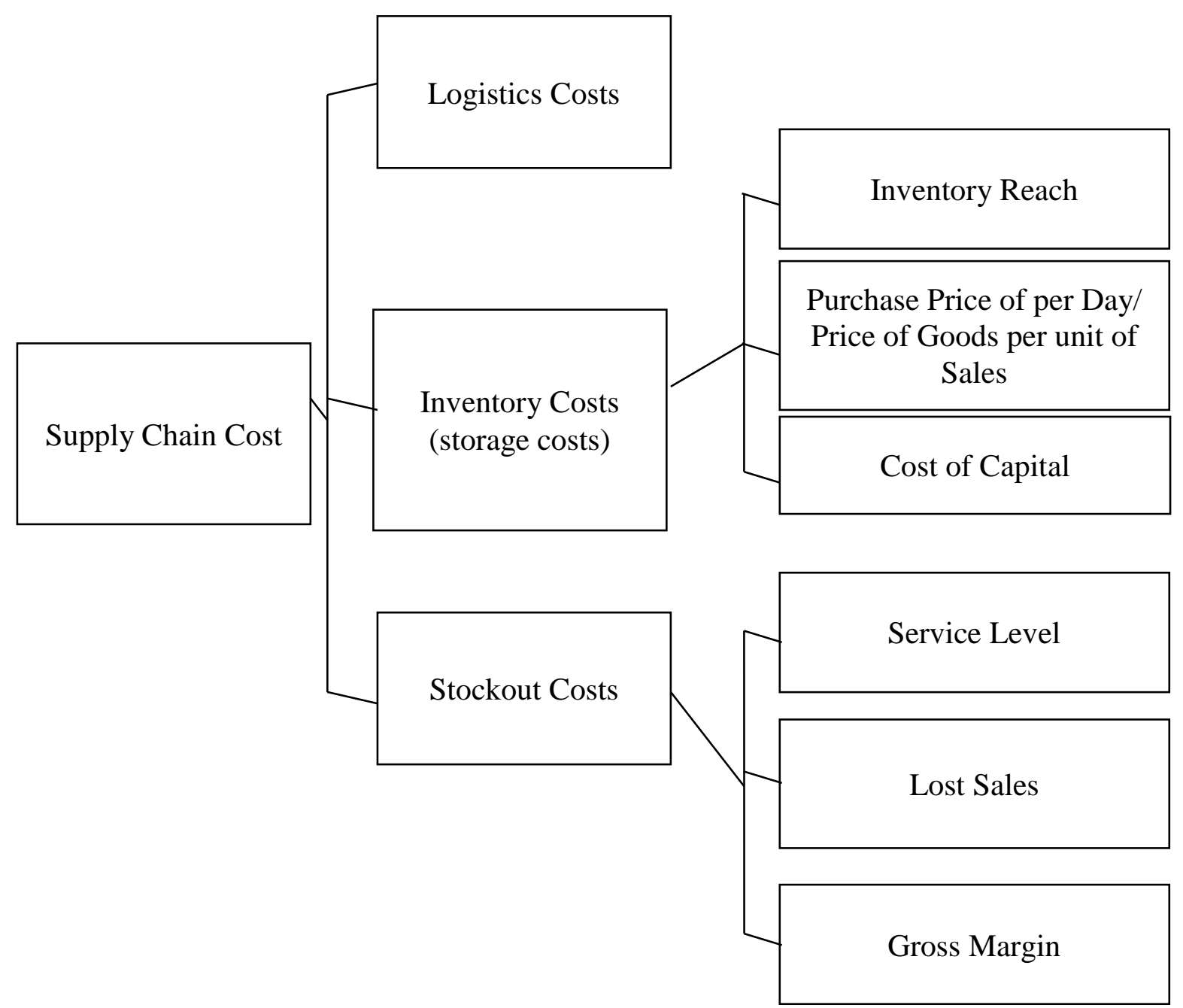

Fig. 3. The elements of Supply Chain Cost

There are two main types of the service level:

1. The service level of the first kind, or cyclical service level (Cycle Service Level, CSL) - a statistical measure that reflects the probability $(P)$ that during the replenishment cycle (from posting applications to obtaining production) there won't be any shortage of resources.

$$
C S L=P(\text { Demand } \leq \text { Inventory }),
$$

where Demand is for the period for which CSL is calculated;

Inventory - the number of stocks at the beginning of the period for which CSL is calculated. 
2. The service level of the second kind or saturation of demand (Fill Rate, $F R$ ) - the share of demand that is guaranteed to be covered by available stocks during the period of their replenishment:

$$
F R=(1-\text { lostDemand } / \text { forecastDemand }) \cdot 100 \%,
$$

where lostDemand - is the forecasted lost demand in physical units;

forecastDemand - is the forecasted demand in physical units.

The cyclic level of service determines either the probability that there will be no deficit within a given time interval or, equivalently, the proportion of time intervals without a deficit. The size of the time interval depends on the type of inventory management policy.

The level of saturated demand service shows the share of customer orders that were satisfied with available stocks.

The optimal level of service of the I or II kinds is the level of service at which total losses on storage of stocks, losses on write-off of products with the expired expiration date, losses from the cash "freezing", and also losses from potential deficit are minimum. Losses from the cash freezing (the cost of alternative investments) are determined in the form of an annual interest rate on the value of inventories in purchase prices. This percentage is usually defined as the current rate on deposits for legal entities that have their own funds and the only alternative use is to open a deposit. If there is an opportunity to invest in the expansion of a business with a certain rate of return, the cost of alternative investments may be recognized as the rate of return. If funds are attracted (credit), they can be used to repay the loan, and the value of alternative investments is determined as the interest rate on the loan.

\section{Modeling of fixed-order supply chain delivery system under uncertain demand}

The specified level of service has a significant impact on the design and organization of efficient chain operation. Typically, in order to keep a certain level of service, in the modeling of the SC resource management systems are used, based on determinism, i.e. accurate determination of management conditions, the size of the re-order, as well as the time of its placement and inventory level. In this case, when re-ordering, a single re-ordering point is determined. In organizing the system of resource supply on market terms, a huge role is played by the uncertainty factor, which limits the application of deterministic models. In such situations, it is necessary to use other approaches that take into account the uncertainty of demand and delivery time. Both of these values fluctuate over time and may not be constant and strictly fixed. The most common is the probabilistic approach for solving this problem. When constructing probabilistic models, it is assumed that demand has the 
characteristics of standard statistical distributions (normal, Poisson, etc.); such models take into account the level of service, i.e. the probability of stock shortages during one cycle of replenishment.

If the level of service is set, then in conditions of uncertainty of demand it can be achieved by increasing the level of re-ordering, adding to the average demand reserve. In such cases, it is necessary to compensate for the increase in the cost of storage of stocks by reducing the cost of their shortage.

Thus, the main calculated indicators in the simulation of the SC are the size of the order, the standard deviation of demand and the duration of the functional cycle, the value of the cyclic, and the insurance margin ${ }^{30,31,32}$.

Problems of optimization of work of various links of the SC are solved by means of models of the theory of stock management ${ }^{33}$. In the basic model of inventory management theory, it is necessary to determine the size of the order, which takes into account the ratio of inventory costs and the cost of placing orders. The main thing here is not to forget that the average stock is equal to half the size of the order. Hence, the larger the batches replenish stocks, the greater the average volume of stocks, and hence the annual cost of their maintenance. On the other hand, the larger the batches of replenishment, the less often you have to place orders, and therefore the lower the total cost of placing orders. The optimal size of the order should be such that the total annual costs of placing orders and maintaining stocks were the lowest for a given sales volume. The main indicators of the model:

$T$ - re-order interval (years);

$\frac{1}{T}=D / q-$ annual number of orders (deliveries);

$\frac{\mathrm{C}_{0}}{T}=C_{0} \cdot \frac{D}{q}-$ overhead costs for sales for the year;

$\frac{q}{2}-$ average level of stocks during the year;

${ }^{30}$ P. Kuzins, R. Lemming, B. Louson, B. Skver. (2010). Strategicheskoye upravleniya tsepochkami postavok: teoriya, organizatsionnyye printsipy i praktika effektivnogo snabzheniya. [Strategic supply chain management: theory, organizational principles and practice of efficient supply]. Moskow: Delo i Servis, 302 p. [in Russian].

31 Brodetskiy G. L. (2008). Upravleniye zapasami. [Management of inventory] Moskow: Eksmo. 352 p. [in Russian].

${ }^{32}$ Shutenko T. M., Semenchuk K. L. (2019). Upravlinnja lancjugom postachan' ta ryzykamy v logistyci. [Supply Chain Management and Logistics Risks]. Inventor's Certificate, no. 88, 546.

${ }^{33}$ Editorial team (2013). Svitlii pamiati zasluzhenoho diiacha nauky i tekhniky Ukrainy, doktora ekonomichnykh nauk, profesora Chekalovtsia Viktora Ihnatovycha - do 75-richchia prysviachuietsia [In memory of the Honored Worker of Science and Technology of Ukraine, Doctor of Economics, Professor Viktor I. Chekalovets - dedicated to the 75th anniversary]. Development of Management and Entrepreneurship Methods on Transport, issue 1(42), pp. 5-7. [in Russian]. 
$\mathrm{C}_{h} \cdot \frac{q}{2}$ - annual costs for storage of products.

The problem of minimizing the total annual costs is represented by function $\mathrm{C}_{\Gamma}(q)$ on variable $q$ :

$$
\mathrm{C}_{\Gamma}(q)=C_{o} \cdot \frac{D}{q}+C_{h} \cdot \frac{q}{2} \rightarrow \min
$$

and/or function $C_{\Gamma}(T)$ on variable $T$ :

$$
\mathrm{C}_{\Gamma}(T)=C_{o} \cdot T+C_{h} \cdot D \cdot \frac{T}{2} \rightarrow \min
$$

The condition $\frac{\partial \mathrm{C}_{\Gamma}}{\partial q}=0\left(\frac{\partial C_{\Gamma}}{\partial T}=0\right)$ allows you to find the optimal value for $q^{*}$ order.

Thus, to minimize the total annual costs it is necessary to find:

1) the economic order quantity $(E O Q)$ that minimizes supply chain total costs relating to ordering, receiving, and holding inventory:

$$
E O Q=q_{i}=\sqrt{2 C_{0} \cdot \frac{D}{C_{h i}}}, i=\overline{1, N}
$$

where $C_{o}-$ cost of placing an order (monetary units per order);

$C_{h i}$ - holding cost (monetary units);

$D$ - annual rate of demand (units);

$i$ - type of product (resource).

$\mathrm{C}_{h i}=k_{h} \cdot U_{i}$, where $k_{h}$ - the share of storage costs per unit value of the product, $U_{i}$ - the gross value of the product (monetary units / ton);

2) the optimal value of the duration of the re-order interval - time interval $T$ between the moments of submission of the next (neighboring) orders:

$$
T_{i}^{*}=\sqrt{2 C_{0} /\left(D * C_{h i}\right)}, i=\overline{1, N}
$$

If the flow of the SC is multi-item, there are several other calculations of the size of the order. Multi-item inventory management models in the SC allow us to take into account any number of $N$ types of product (resource) $i$ $(i=\overline{1, N}$ ), for each of which a stock is planned. The delivery of all products is general each time, i.e. all types of analyzed products are presented in the batch, in addition, the size of the order for each type of product is different.

Suppose that the lack of inventory for each product $i$ is unacceptable; demand for the product is constant; $D_{i}$ - average demand for a single time interval; the deliveries are general; $T_{0}$ - re-order interval; $\frac{1}{T_{0}}$ - total number of deliveries; $\frac{q_{i}}{2}-$ average annual level of product $i$ stock. 
The value of total annual costs is determined by the formula:

$$
\mathrm{C}_{\Gamma}=C_{0} *\left(\frac{1}{T}\right)+\sum_{i=1}^{N} C_{h i} *\left(\frac{q}{2}\right),
$$

for any fixed $T=T_{o}$ we have $q_{i}=T_{0} * D_{i}$.

Accounting for the value of each type of product $i$ gives an additional term $\sum_{i=1}^{N} C_{h i} * D_{i}$, which doesn't depend on $q_{i}$, either $T$ or therefore does not affect the optimum point of the function of minimizing total costs.

Let's reduce the problem of finding the optimal inventory management strategy to the problem of minimizing the total costs represented by function $C_{\Gamma}\left(T_{0}\right)$ on variable $T_{0}$ :

$$
\mathrm{C}_{\Gamma}\left(\mathrm{T}_{0}\right)=C_{0} *\left(\frac{1}{T_{0}}\right)+\frac{T_{0}}{2} *\left(\vec{D} * \overrightarrow{C_{h}}\right) \rightarrow \min ,
$$

where $\vec{D}=\left(D_{1}, D_{2}, \ldots, D_{N}\right)$ - is the vector of annual consumption of products;

$\overrightarrow{C_{h}}=\left(C_{h 1}, C_{h 2}, \ldots, C_{h N}\right)-$ is the vector of storage tariffs;

$\vec{D} * \overrightarrow{C_{h}}-$ scalar product of vectors.

The first summand in the right part of the presented expression (as a function of variable $T_{0}$ ) - is a hyperbola, the second term is a linear function.

Let us find the optimal value of the interval between total deliveries to minimize total annual costs.

The re-order interval (total) is:

$$
T_{0}^{*}=\sqrt{2 C_{0} /\left(\vec{D} * \overrightarrow{C_{h}}\right)} \text { (days). }
$$

The economic order quantity (for product $i$ ):

$$
q_{i}^{*}=D_{i} * \sqrt{2 C_{0} /\left(\vec{D} * \overrightarrow{C_{h}}\right)} \text { (days). }
$$

According to the type (single-item or multi-item) and options for servicing the flow of products (resources), we can distinguish the SC delivery system with decentralized and centralized inventory allocation.

With decentralized inventory allocation, the main indicator that affects the level of service is the deviation of the volume of the order (demand) and the duration of the order execution cycle (lead time).

Standard deviation with a combination of random events (booking volume and order fulfillment cycle time are exposed to uncertainty) for the product $i$ is: 


$$
\sigma_{D L T}^{i}=\sqrt{T_{i}\left(\sigma_{D}^{i}\right)^{2}+\left(D_{i}\right)^{2}\left(\sigma_{L}^{i}\right)^{2}}
$$

where $T_{i}$ - the average duration of the functional cycle of delivery of the $i$-th product (in units of time); $D_{i^{-}}$the average demand (in units of demand); $\sigma_{D}^{i}$ - the standard deviation of the volume of demand for a set unit time interval; $\sigma_{L^{-}}^{i}$ the standard deviation of the duration of the functional cycle.

In decentralized customer service, the duration of the functional cycle is constant, therefore, $\sigma_{L}^{i}=0$ and, as a consequence:

$$
\sigma_{D L T}^{i}=\sqrt{T_{i}\left(\sigma_{D}^{i}\right)^{2}}=\sigma_{D}^{i} \sqrt{T_{i}}
$$

Safety stock (SS):

$$
\begin{gathered}
S S=f \sigma_{D L T}^{i}=\sum_{i=1}^{n}\left(k_{C S L}^{i} \cdot \sigma_{D L T}^{i}\right)= \\
=\sum_{i=1}^{n} k_{C S L}^{i}\left(\sqrt{T_{i}\left(\sigma_{D}^{i}\right)^{2}+\left(D_{i}\right)^{2}\left(\sigma_{L}^{i}\right)^{2}}\right) .
\end{gathered}
$$

$k_{C S L^{-}}^{i}$ the coefficient corresponding to the set value of the service level in the supply chain (risk coverage).

The Total Cycle Stock (TCS), is determined by the formula:

$$
T C S=\frac{\sum_{i=1}^{n} q_{i}}{2}+S S .
$$

Designing a centralized maintenance of the flow of stocks is possible in the delivery system of the SC, which concentrates the flow of stocks in one accumulative-distributing center, performing the function of aggregation of stocks and able to serve all the declared demand. Total (aggregate) demand $\left(D^{c}\right)$, formed by all consumers of services for storage and distribution of stock (the flow of stocks is multi-item), subject to the normal law of distribution. The nature of product demand can be dependent and independent.

$$
\begin{gathered}
D^{c}=\sum_{i=1}^{N} q_{i}^{*} ; \\
\sigma_{D}^{C}=\sqrt{\sum_{i=1}^{N}\left(\sigma_{D}^{i}\right)^{2}+2 \sum_{i>j} \rho_{i j} \sigma_{D}^{i} \sigma_{D}^{j}},
\end{gathered}
$$

where $\rho_{i j}-$ is the correlation coefficient. 
If demand is an independent quantity (correlation coefficient $\rho_{i j}=0$ ):

$$
\sigma_{D}^{C}=\sqrt{\sum_{i=1}^{N}\left(\sigma_{D}^{i}\right)^{2}}
$$

then the duration of the order in the center of consolidation is equal $T^{c}$ to the standard deviation $\sigma_{T}^{C}$. Demand $D_{D L T}^{C}$ is concentrated in the central node:

$$
\sigma_{D L T}^{C}=\sqrt{T^{c}\left(\sigma_{D}^{C}\right)^{2}+\left(D^{c}\right)^{2}\left(\sigma_{T}^{C}\right)^{2}} .
$$

Assuming that the order execution time $\left(T^{c}\right)$ is constant:

$$
\sigma_{D L T}^{C}=\sqrt{T^{c}\left(\sigma_{D}^{C}\right)^{2}}=\sigma_{D}^{C} \sqrt{T^{c}},
$$

then the amount of safety stock $\left(S S^{c}\right)$ is defined as:

$$
S S^{c}=f \sigma_{D L T}^{C}=K_{C S L}^{C} \sigma_{D L T}^{C}=K_{C S L}^{C} \sqrt{T^{c}\left(\sigma_{D}^{C}\right)^{2}+\left(T^{c}\right)^{2}\left(\sigma_{T}^{C}\right)^{2}} .
$$

$k_{C S L^{-}}^{c}$ is the coefficient corresponding to the set value of the level of service for centralized deliveries.

In the case when the execution time of the order duration $\left(T_{C}\right)$ is constant:

$$
S S^{c}=K_{C S L}^{c}\left(\sigma_{D}^{C} \sqrt{T^{c}}\right) .
$$

The total cycle stock is:

$$
T C S^{c}=\frac{D^{c}}{2}+S S^{C} .
$$

Thus, the volume of orders and stocks for each type of product (resource) is determined by their specifics, fluctuations in the delivery system, the importance of individual tasks. Managers of the design and organization of the effective operation of the SC team are responsible for the motion of flows, inventories and balance the overall supply of products and the initial (distribution) flows of resources for the tasks of the SC. In real practice, there is always an element of randomness and uncertainty, the timing of tasks and the volume of deliveries can vary. Clear coordination of actions at all levels of competence of project and operational management is necessary to ensure the planned course of work of the SC.

\section{CONCLUSIONS}

The trends in the development of projects and programs are characterized by digitization, globalization, transition to Agile transformation, and business projection. The Classifier of Professions in Ukraine does not reflect all 
positions of today. By searching for the word "project", the Classifier implies a Chief Architect, Chief Designer, Chief Engineer, etc. The disadvantage of the Classifier is the lack of new, modern professions related to project and program management. The development of the Agile environment has also affected the professional work of project management, giving rise to many professions that need detailed consideration. The most important ones from today's point of view are Project Manager, Project Curator, Project Coordinator, Administrator, PR-Manager, Supply Chain Designer, etc.

Agile specialists allow us to use changes to provide the project customer with competitive advantages. At present, there is a need for competent Agilespecialists who must have the ability to sustainably develop, have the motivation to adapt and grow, which drives the project team to these changes. Agile-specialists or agile-leaders are able to deliver project results through the tools and resources available, through systematic and strategic thinking, as well as resourcefulness and a situational approach, that allows any change to be made to deliver the project with a competitive advantage in a dynamic environment.

The task of designing efficient supply chains is important and quite complex. The SC design is a complex process by which the organization forms the structure and manages the SC in order to ensure the necessary balance between stocks, transportation and production cost.

Supply chain agility is the ability of the supply chain as a whole to rapidly align the network and its operations to the dynamic and turbulent requirements of customers' demands.

Volatility in demand, shortening of the product life cycle or increased competition require that SCs act in accordance with end-user oriented strategies. The tactics, resources, and changes that need to take place become concrete and measurable in advance. The same tactic organizes communication and behavior in a timely manner.

The use of project management in the organization of supply chains creates order and predictability among the complex and variable requirements of consumers.

Much is involved in the process of organizing the supply chain before the project reaches the completion stage. In this process, knowledge of the project life cycle in the supply chain is important. The life cycle phases of a SCM project are the improvement of processes and systems, which can be both short-term and long-term.

Supply chain improvements are based on the concepts of Lean Management and Agile Management. The goal of dynamic (Agile) supply chains is to increase the level of service by increasing the speed of response to consumer requests and flexibility in relation to surplus components (high 
inventory, availability of distribution centers near consumers, etc.) taking into account the uncertainty of demand.

\section{SUMMARY}

The symbiosis of knowledge of project management, logistics and supply chain management allows you to systematically organize the process of managing investment, material, service, financial, information flows, as well as requires modern competencies of Agile-specialists. Agile specialists are ready to adapt to a dynamic environment and constant change, have a systematic and strategic thinking, as well as ingenuity and situational approach to achieve competitive advantage in a dynamic environment.

During the project implementation, logistics and supply chain management cover almost the entire range of resource and functional support from the processes of initiation to closure. Such processes are implemented in a sequence of phases, stages and works of the life cycle, and their effective implementation is based on the rules of logistics through supply chains and coordinated interaction of participants.

Agile supply chains are thus relevant for innovative products where demand is unpredictable. The supply chain project management enables an organization to react quickly and more effectively to marketplace volatility and other uncertainties, thereby allowing the organization to establish a superior competitive position.

\section{REFERENCES}

1. A Guide to the Project Management Body of Knowledge. (2017). [PMI, Sixth edition], 976 [in English].

2. Bushuyev S. D. (2018). Rukovodstvo IPMA ICB4 v mire Agile [Agile IPMA ICB4 Guide], 72 [in Russian].

3. Reyting luchshikh professiy po versii Glassdoor [Glassdoor Ranking Best Professions] (2017). URL: https://hightech.fm/2017/01/25/ glassdoor-2.

4. Lapkina I. A., Pavlovskaya L. A., Boldyreva T. V. \& Shutenko T. N. (2008). Proyektniy analiz. Teoreticheskiye osnovy otsenki proektov na morskom transporte. Odessa: ONMU, 367[in Russian].

5. Lapkina I. O., Semenchuk K. L. (2014). Upravlinnya protsesamy v proyekti. Odesa: ONMU, 115. ISBN 978-966-7716-74-5. [in Ukrainian].

6. Semenchuk K. L. (2012). Stratehichnyy menedzhment. Praktykum z obgruntuvannya stratehichnykh rishen' dlya transportnykh pidpryyemstv. Odesa: ONMU, 2012, 228. ISBN 978-966-7716-68-4. [in Ukrainian].

7. Lapkina I. (2015). Risk management in syllabuses of Odessa National Maritime University [Risk management and assessment for prevention of ecological and technological risk in the Black Sea basin. 09-12 July 2015, 
Burgas, Project 2.2.21.73194.264 "Creation of Interuniversity center for risk management and assessment for prevention of ecological and technological risk in the Black Sea basin. Joint Operational Programme "BLACK SEA BASIN" for Romania]. Conctanta: Editura Nautica. P. 504-505. ISBN 978-606-681-069-2.

8. ICB. IPMA Competence Baseline (2006). [IPMA, Version 3.0], 199 [in English].

9. Bushuyev S. D. (2010). Upravleniye proêktami: osnovy professional'nykh znaniy i sistema otsenki kompetentnosti proêktnogo menedzhmenta [National Competence Baseline, NCB UA Version 3.1] / Bushuyev S. D., Bushuyeva N. S. Second edition. K.: ÍRÍDÍUM. 208. [in Russian].

10. Klasifikator profesiy Ukrayiny DK 003:2010. URL: https://buhgalter911.com/ spravochniki/ klassifikatory/klasifikator-profesiy.

11. V Davose obsuzhdali neobkhodimost' mirovoy revolyutsii po pereobucheniyu kadrov: prichina. URL: https: https://rubryka.com/ru/ 2020/01/26/retraining-personnel-davos/.

12. Semenchuk K. L. (2020). Upravlinnya proektamy Agile-spetsialistamy [Project Management of Agile-Specialists]. Development of Management and entrepreneurship methods on transport, no. 2(71). [in Ukrainian].

13. Proyektnyy ta lohistychnyy menedzhment: novi znannya na bazi dvokh metodolohiy. (2018). Tom 1: monohrafiya / [avt.kol.: S. V. Rudenko, I. O. Lapkina, T. A. Kovtun \& in.]. Odesa. 188. DOI: 10.21893/2616-8936.2018-01. [in Ukrainian].

14. Pryektnyy ta lohistychnyy menedzhment: novi znannya na bazi dvokh metodolohiy. (2019). Tom 2: monohrafiya / [avt. kol.: I. O. Lapkina, V. O. Andryyevs'ka, V. YU. Smrkovs'ka \& in.]. Odesa. 242. DOI: 10.21893/2616-8936.2019-02. [in Ukrainian.

15. Asthana, S. G. (2018). Making Sense of Supply Chain 4.0: what, exactly, can 'digital transformation' improve upon? [Industryweek]. URL: https://www.industryweek.com/supply-chain/article/22026620/making-senseof-supply-chain-40 (accessed 20 April 2020).

16. Kubasova T. I. (2009). Logistika i logisticheskiy menedzhment ipotechno-stroitel'nykh proyektov [Logistics and logistics management of mortgage construction projects]. Sankt-Peterburg: Sankt-Peterburgskogo gos. un-ta ekonomiki i finansov. 250 p. [in Russian].

17. Reeve J. M. \& Srinivasan M. M. (2005). Which supply chain design is right for you? [Supply Chain Management Review]. pp 50-57.

18. Semenchuk Ye. L., Shutenko T. N. (2015). Integratsiya sudokhodnoy kompanii $\mathrm{v}$ tsepyakh postavok [Integration of the shipping company in supply chain]. East Ukraine National University of V.Dahl, no. 2 (219), pp. 18- 22. [in Russian]. 
19. Forrester J. W. (1958). Industrial Dynamics: A Major Breakthrough for Decision Makers. [Harvard Business Review]. no. 36 (4), pp 37-66.

20. Soonhong Min, Zach G. Zacharia, and Carlo D. Smith. (2019). Defining Supply Chain Management: In the Past, Present, and Future. Journal of Business Logistics. no. 40(1), pp. 44-55.

21. Nel J. D., Badenhorst-Weiss. (2010). Supply chain design Some critical questions. URL: https://www.researchgate.net/publication/307846614 (accessed 25 April 2020).

22. Shutenko T. N. (2011). Analiz sredy funktsionirovaniya logisticheskoy sistemy. [Analiz sredy funktsionirovaniya logisticheskoy sistemy.]. Proceeding of the Odessa National Maritime University. Odessa: Astroprint, no. 32, pp. 195-203. [in Russian].

23. Apics Supply Chain Council. Enhancing Project Management. URL: http://www.apics.org/docs/default-source/industry-content/apics-enhancingproject. (accessed 20 April 2020).

24. James B. Ayers. (2006). Handbook of supply chain management. [Auerbach Publication, $2^{\text {nd }}$ ed]. 658.

25. Semenchuk Ye. L. (2011). Stratehyy razvytyya sohlasno zhyznennomu tsyklu sudokhodnoy kompanyy. [The strategic development is according with the life cycle of the shipping company]. Proceeding of the Odessa National Maritime University, Odessa: ONMU. No. 32. pp. 161-169. [in Russian].

26. Semenchuk Ye. L. (2007). Videniye zhiznennogo tsikla proyekta razvitiya sudokhodnoy kompanii s pozitsiy razlichnykh yego uchastnikov. [Vision of the life cycle of a shipping company development project from the perspective of its various participants]. Project Management and development of production. Lugansk: V. Dahlya of SNU, no. 3 (23), pp. 95-102. [in Russian].

27. Lee H. L. (2005). Sekret najbardziej efektywnych łańcuchów dostaw. [Harvard Business Review Polska], no. 25, pp. 78-92.

28. Mason-Jones R., Naylor B. \& Towill D. R. (2000). Lean, agile or leagile? Matching your supply chain to the marketplace. [International Journal of Production Research], no. 38(17), pp. 4061-4070.

29. K. Behrenbeck, A. Brinkhoff, J. Grobpietsch. (2008). How to become a Supply Chain Champion. Hard fact about soft factors. [McKinsey\&Company]. $173 \mathrm{p}$.

30. Garrison A., Van Gok R. (2010). Logistika. Strategiya upravleniya i konkurirovaniya cherez tsepochki postavok. [Logistics. Supply Chain Management and Competition Strategy]. Moskow: Delo i Servis. 368. [in Russian].

31. P. Kuzins, R. Lemming, B. Louson, B. Skver. (2010). Strategicheskoye upravleniya tsepochkami postavok: teoriya, organizatsionnyye printsipy i praktika effektivnogo snabzheniya. [Strategic supply chain management: 
theory, organizational principles and practice of efficient supply]. Moskow: Delo i Servis, 302 p. [in Russian].

32. Brodetskiy G. L. (2008). Upravleniye zapasami. [Management of inventory]. Moskow: Eksmo. 352. [in Russian].

33. Shutenko T. M., Semenchuk K. L. (2019). Upravlinnja lancjugom postachan' ta ryzykamy v logistyci. [Supply Chain Management and Logistics Risks]. Inventor's Certificate, no. 88, 546.

\section{Information about the authors:}

Lapkina I. O.,

Professor, Doctor of Economic Sciences,

Head of the Department

"Logistics Systems and Projects Management",

Odessa National Maritime University

34, Mechnikov str., Odessa, 65029, Ukraine

ORCID ID: orcid.org/0000-0001-7468-8993

Semenchuk K. L.,

$\mathrm{PhD}$, Associate Professor,

Associate Professor at the Department

"Logistics Systems and Projects Management",

Odessa National Maritime University 34, Mechnikov str., Odessa, 65029, Ukraine ORCID ID: orcid.org/0000-0002-1808-448X

Shutenko T. M., $\mathrm{PhD}$, Associate Professor, Associate Professor at the Department "Logistics Systems and Projects Management", Odessa National Maritime University 34, Mechnikov str., Odessa, 65029, Ukraine ORCID ID: orcid.org/0000-0001-9425-8026 